\title{
Biotechnological Importance of Torulaspora delbrueckii: From the Obscurity to the Spotlight
}

\author{
Ticiana Fernandes ${ }^{1,2} \mathbb{D}$, Flávia Silva-Sousa ${ }^{1,2} \mathbb{D}$, Fábio Pereira ${ }^{1,2}$, Teresa Rito ${ }^{1,2} \mathbb{D}$, Pedro Soares ${ }^{1,2}$, \\ Ricardo Franco-Duarte ${ }^{1,2, *(\mathbb{D})}$ and Maria João Sousa ${ }^{1,2}$ (D)
}

1 CBMA (Centre of Molecular and Environmental Biology), Department of Biology, University of Minho, 4710-057 Braga, Portugal; tixand.tf@gmail.com (T.F.); sousa.s.flavia@gmail.com (F.S.-S.); pg40079@alunos.uminho.pt (F.P.); teresarito@bio.uminho.pt (T.R.); pedrosoares@bio.uminho.pt (P.S.); mjsousa@bio.uminho.pt (M.J.S.)

2 Institute of Science and Innovation for Bio-Sustainability (IB-S), University of Minho, 4710-057 Braga, Portugal

* Correspondence: ricardofilipeduarte@bio.uminho.pt or ricardofrancoduarte@gmail.com; Tel.: +351-253-604-310; Fax: +351-253-678-980

Citation: Fernandes, T.; Silva-Sousa,

F.; Pereira, F.; Rito, T.; Soares, P.;

Franco-Duarte, R.; Sousa, M.J.

Biotechnological Importance of Torulaspora delbrueckii: From the Obscurity to the Spotlight. J. Fungi 2021, 7, 712. https://doi.org/ 10.3390/jof7090712

Academic Editor: Jose Ramos

Received: 9 August 2021

Accepted: 25 August 2021

Published: 30 August 2021

Publisher's Note: MDPI stays neutral with regard to jurisdictional claims in published maps and institutional affiliations.

Copyright: (c) 2021 by the authors. Licensee MDPI, Basel, Switzerland. This article is an open access article distributed under the terms and conditions of the Creative Commons Attribution (CC BY) license (https:/ / creativecommons.org/licenses/by/ $4.0 /)$.

\begin{abstract}
Torulaspora delbrueckii has attracted interest in recent years, especially due to its biotechnological potential, arising from its flavor- and aroma-enhancing properties when used in wine, beer or bread dough fermentation, as well as from its remarkable resistance to osmotic and freezing stresses. In the present review, genomic, biochemical, and phenotypic features of T. delbrueckii are described, comparing them with other species, particularly with the biotechnologically wellestablished yeast, Saccharomyces cerevisiae. We conclude about the aspects that make this yeast a promising biotechnological model to be exploited in a wide range of industries, particularly in wine and bakery. A phylogenetic analysis was also performed, using the core proteome of T. delbrueckii, to compare the number of homologous proteins relative to the most closely related species, understanding the phylogenetic placement of this species with robust support. Lastly, the genetic tools available for T. delbrueckii improvement are discussed, focusing on adaptive laboratorial evolution and its potential.
\end{abstract}

Keywords: Torulaspora delbrueckii; non-Saccharomyces; wine; bread; biotechnology; genomics

\section{Introduction}

Non-Saccharomyces yeasts were described for many years as sources of spoilage and contamination, and are also associated with a negative contribution to the organoleptic profile of wines. However, in recent decades, wines produced by some non-Saccharomyces yeasts revealed distinct and unique characteristics attracting the attention of many research groups [1]. Improved wines are obtained benefiting from their physiological and metabolic features, which have a positive effect on the wine's sensorial and chemical properties, namely in terms of sugar and acid consumption, alongside an enhanced aroma complexity through the release of important metabolites [2-4]. Within this group of yeasts, Torulaspora delbrueckii stands out as one of the most advantageous non-Saccharomyces species due to its potential to introduce diversity and multiplicity to the standard wine's market, currently established by the use of Saccharomyces cerevisiae [5]. The rising interest in T. delbrueckii is reflected by the number of scientific publications involving this species. According to the Web of Science ${ }^{\mathrm{TM}}$ database, between the years 1987 and 2013, an average of eight publications per year were related to the topic T. delbrueckii (search queries by title, abstracts and keywords), and this number is continuously growing with a 6-fold increase between 2013 and 2021.

In the present review, we explored available information on the biochemical, genomic and phenotypic features of T. delbrueckii, with special emphasis on the aspects that make this yeast a promising biotechnological model to be exploited in a wide range of industries, 
but particularly in wine and bakery. Genomic, phenotypic, and metabolic characteristics of T. delbrueckii were scrutinized to enrich the understanding of this non-Saccharomyces yeast, comparing it with the yeast well-established in the market, S. cerevisiae. In addition, the importance of applying genetic tools towards T. delbrueckii improvement was highlighted.

\section{Occurrence and General Characteristics}

Yeasts from the genus Torulaspora have been reported in a wide variety of habitats, such as fruits [6], insects [7,8], soils [9], soil invertebrates [10], plants [11,12], seawater [13], spoiled food [6] and malt environments [6], where yeast from other genera like Saccharomyces and Zygosaccharomyces may also be present [14,15]. Although not considered a human pathogen, the species T. delbrueckii can also be found as a clinical isolate [16]. In addition to the diversified isolation substrates, $T$. delbrueckii also presents a worldwide geographical distribution, with reports describing its isolation in 37 countries from the five continents, as shown in Figure 1

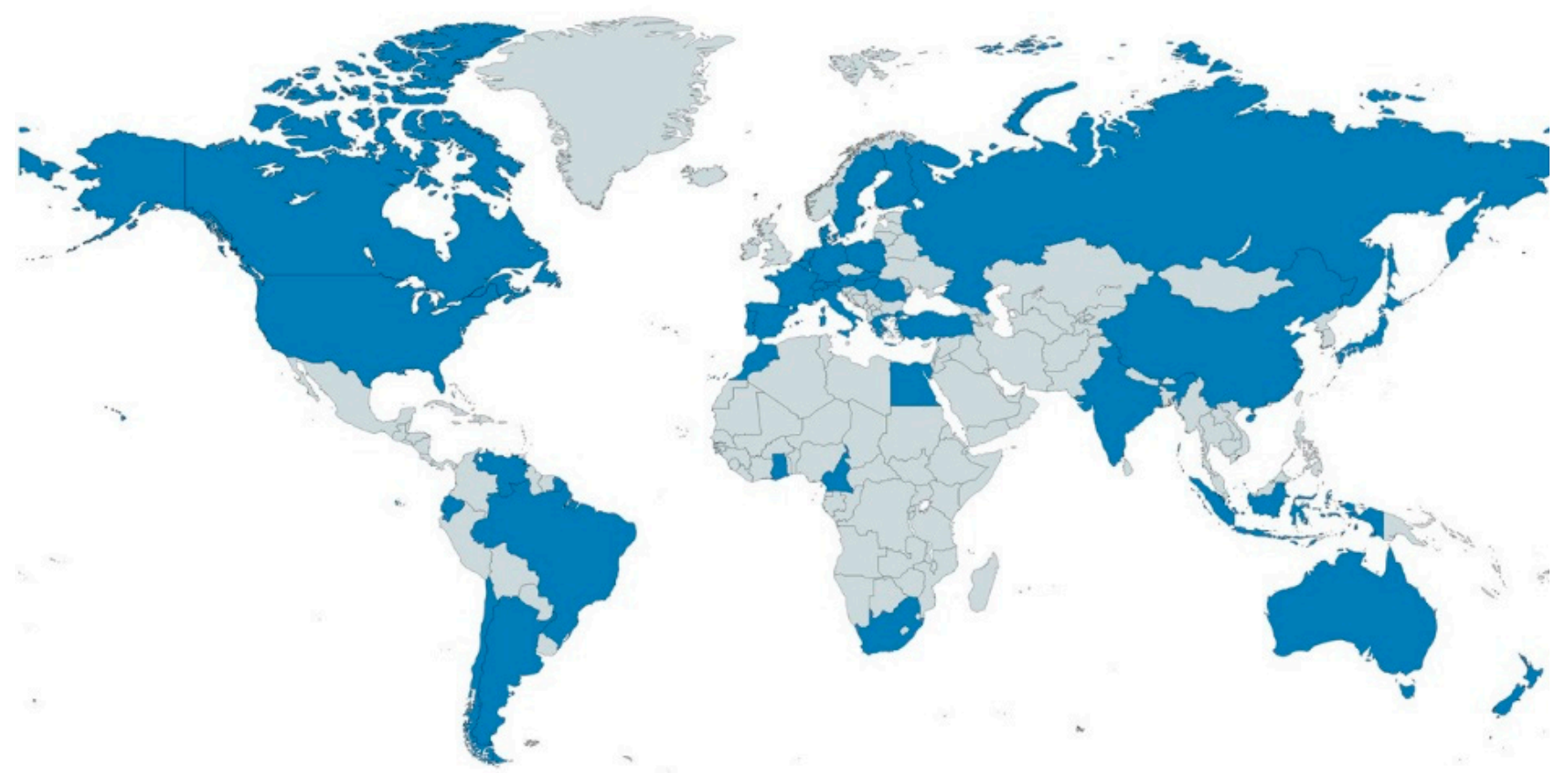

Figure 1. Geographical distribution of Torulaspora delbrueckii. Countries in which T. delbrueckii isolation was reported are highlighted in blue. Data were collected from Albertin et al. [6], Drumonde-Neves et al. [1] and de Vuyst et al. [17].

Species belonging to the genus Torulaspora can reproduce asexually by cell division (budding division) or sexually through asci, containing one to four spherical ascospores, characteristic of ascomycetous yeasts $[4,18,19]$. Regarding its shape, Torulaspora yeasts are mainly discerned by spherical cells (hence the torulu terminology), but also ovoid and ellipsoidal forms, with dimensions of approximately $2-6 \times 3-7 \mu \mathrm{m}$, which are smaller than those of $S$. cerevisiae. The sharing of multiple morphological and physiological characteristics between some species has led to a misclassification of some of them. Within the genus Torulaspora, four strains presumed to be T. delbrueckii were later reclassified into the genera Debaryomyces and Saccharomyces. Currently, this group includes at least six species: T. delbrueckii (anamorph Candida colliculosa), T. franciscae, T. pretoriensis, T. microellipsoides, T. globosa and T. maleeae [20]. Two other species-T. indica and T. quercuum-have also been proposed to be included in this genus, after the employment of molecular tools to discriminate them [21]. For many years, T. delbrueckii was described as a haploid yeast, essentially because of its small cell size and due to the rare detection of tetrads in sporu- 
lation media [20]. However, Albertin et al. [6] suggested that this species may be mainly diploid. The reduced size of this yeast is not, in this way, associated with the ploidy level, and may be explained by the fact that $T$. delbrueckii only possesses 16 chromosomes in the diploid phase, instead of the 32 chromosomes found in S. cerevisiae diploid yeasts [20]. Given the lack of deep knowledge about the life cycle of T. delbrueckii, it is still difficult to design strategies for the biotechnological improvement of T. delbrueckii using classical genetic techniques such as those commonly proposed for S. cerevisiae [22]. New techniques are, in this way, being explored, as will be detailed further.

The phylogenetic proximity between T. delbrueckii and S. cerevisiae may contribute to explain why T. delbrueckii is one of the non-Saccharomyces yeasts suggested to be most promising for use in biotechnological industries, especially the ones using fermentative processes such as wine- or bread making. T. delbrueckii was one of the first non-Saccharomyces species to be applied commercially in wines, even though only a few species are available in companies' catalogues: Prelude ${ }^{\mathrm{TM}}$, Biodiva $^{\mathrm{TM}}$, Zymaflore $^{\circledR}$ Alpha, Vinifer NS ${ }^{\mathrm{TD}}$, and Primaflora ${ }^{\circledR}$ VB BIO [4].

\section{Genomics and Taxonomy}

In opposition to the extensive knowledge about $S$. cerevisiae genome, the most thoroughly annotated eukaryotic organism [23], there has been a hinder in progress regarding T. delbrueckii genomic characterization, also delaying the understanding of the genomics underlying the unique aptitudes showed by this species, in comparison with other yeasts. The genome of T. delbrueckii type strain CBS1146 is organized in eight chromosomes, it is $9.52 \mathrm{Mb}$ long and has a GC content of 41.9\% [24]. Recently, our in-depth study [25] analysed publicly available genomes of $T$. delbrueckii strains, improving their annotation and concluding about important intra-strain differences. In terms of genome size, variations between $9.22 \mathrm{Mb}$ and $11.53 \mathrm{Mb}$ were found. This variation corresponds also to a diverse number of protein-coding genes being annotated (between 464 and 503). Interestingly, the similarity obtained when analysing pairwise comparisons between the four tested strains' genomes was only as high as $99.63 \%$, and in one case was as low as $97.62 \%$. The improved genome annotation obtained in this work allowed to extend this diversity to a particular functional characterization, showing inter-strain differences in proteins related to ATP-synthesis, proton transports, biosynthesis of inositol and resistance to antiviral Brefeldin A. These differences highlight the importance of using different yeast strains in beverages production (and also in other biotechnological applications), improving their quality and diversity.

T. delbrueckii belongs to the phylum Ascomycota, subphylum Saccharomycotina, class Saccharomycetes, order Saccharomycetales, family Saccharomycetaceae. In our previous work [25] we detailed the T. delbrueckii phylogenetic placement in relation to 386 other fungal species/strains, concluding about the proximity between this species and the genera Zygosaccharomyces and Zygotorulaspora. Our results were in accordance with the work of Shen et al. [26], which showed the phylogenetic reconstruction of more than 300 budding yeasts, even though the $T$. delbrueckii branch was concluded as not being robustly supported. Aiming at elucidating the proximity between the three genera-Torulaspora, Zygosaccharomyces and Zygotorulaspora - we performed a robust phylogenetic reconstruction, filling this gap with the inclusion of additional genomes publicly available in NCBI. As can be depicted in Figure 2, all the 15 available genomes of T. delbrueckii were grouped together in a single isolated clade (highlighted in green in Figure 2), separated from the ones of T. pretoriensis, T. franciscae, T. maleae, T. globosa and T. microellipsoides. The large branch containing all genomes of the genus Torulaspora revealed to be isolated from Zygotorulaspora clade (containing species Zygotorulaspora florentina and Zygotorulaspora mrakii, and highlighted in red in Figure 2). In addition, both these genera-Torulaspora and Zygotorulaspora-formed an isolated group, separated from the one containing Zygosaccharomyces species (highlighted in blue in Figure 2). 


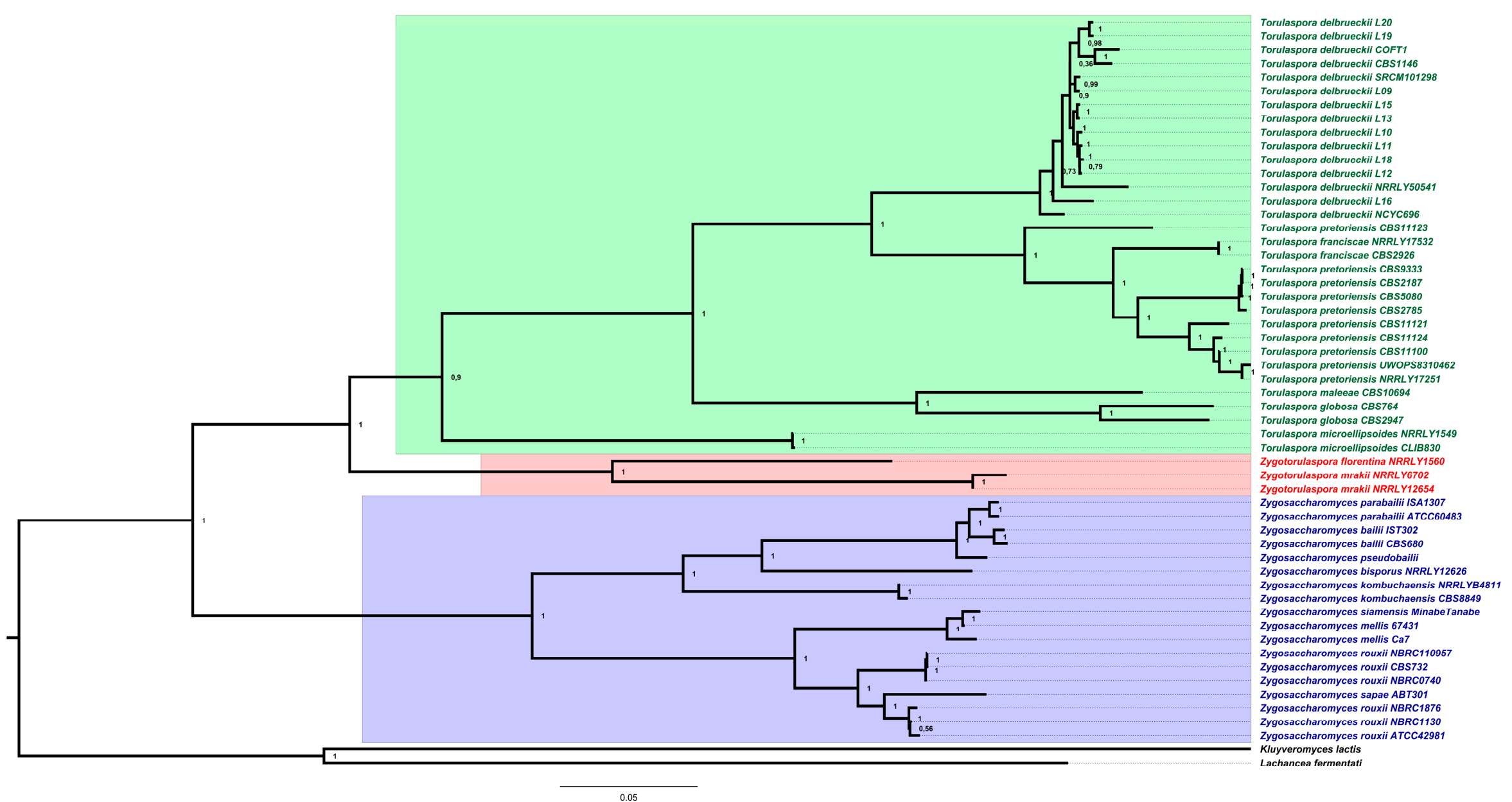

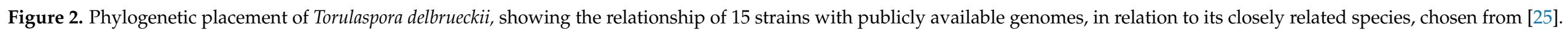

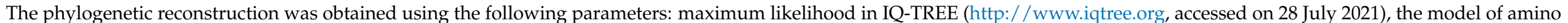

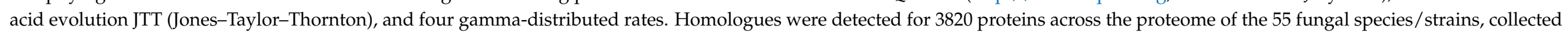

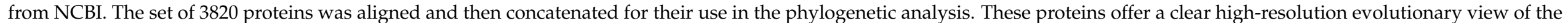
different species, as they are essential proteins beyond the specific biology of the different yeasts. Bootstrapping provided values of $100 \%$ for most nodes. 


\section{Metabolism}

Concerning T. delbrueckii fermentative behaviour, no consensus has yet been gathered regarding its fermentative power. Some authors characterized this species as having a good fermentation performance in wines [3,4,14,20]. Bely et al. [14] even categorized T. delbrueckii as having a performance 9 to $10 \%$ higher when considering other non-Saccharomyces yeasts. On the contrary, Belda et al. [27] and Loira et al. [28] concluded that Torulaspora spp. have lower fermentative power. Still, Almeida and Pais [29] described similar fermentation ability for T. delbrueckii and S. cerevisiae strains in bread dough. These observations could support the idea of a strain dependent profile with respect to the fermentative capacity of this species, which is also supported by our unpublished data showing a heterogenous performance when analyzing a collection of T. delbrueckii strains.

T. delbrueckii presents poor fructose and glucose consumption under conditions of high ethanol and moderate acetic acid concentrations, that can be present in stuck wine fermentations, although it can survive in this environment. This behavior has been associated with the sensitivity of its hexose transport to the inhibitory effect of ethanol $[30,31]$. To address this limitation, a hybrid strain (F1-11) was constructed by Santos et al. [31] combining the advantageous characteristics of high tolerance to both ethanol and acetic acid of T. delbrueckii, and the high hexose consumption of S. cerevisiae. This hybrid exhibited a hexose consumption comparable to the one of the S. cerevisiae and revealed improved resistance to ethanol and acetic acid, presenting lower cell death rates.

Comparatively, both $T$. delbrueckii and S. cerevisiae species behave quite particularly regarding oxygen availability. As the oxygen feed rate decreases, $S$. cerevisiae is the first yeast to switch to a respiro-fermentative metabolism, thus exhibiting lower biomass yields at reduced amounts of oxygen, in comparison to T. delbrueckii, which is able to maintain full respiration under these conditions, translating into a lower fermentation strength and a slower growth rate [32]. This occurrence could be less favorable in a winemaking environment since wine production is usually performed under strictly anaerobic conditions (e.g., white, and sparkling wine), or in the presence of very low oxygen concentrations (e.g., red wines) [33].

Even though T. delbrueckii possesses lower tolerance to low-oxygen conditions [14,34], its metabolism is usually associated with several positive characteristics, mainly regarding the wine industry, related to high osmotic and sulphur dioxide resistance [23-28,35], enhanced capacity for biotransformation of terpenes [28,36,37], or high competence to produce lactic and succinic acids $[28,36]$.

The volatile acidity associated with wine is mainly due to the presence of acetic acid which, above a threshold of $0.8 \mathrm{~g} / \mathrm{L}$ is considered as negatively affecting the quality of the product, contributing to a vinegar character. Regarding acetic acid production, T. delbrueckii presents an advantage towards $S$. cerevisiae, since it typically produces lower levels. In fact, according to Bely et al. [14], it originated between $0.27 \mathrm{~g} / \mathrm{L}$ and $0.56 \mathrm{~g} / \mathrm{L}$ of acetic acid, even in high-sugar fermentations, while $S$. cerevisiae produced amounts ranging between 1.0 and $1.17 \mathrm{~g} / \mathrm{L}$. Values reported for S. cerevisiae can be even higher under some conditions, reaching up to $1.8 \mathrm{~g} / \mathrm{L}$ [14,20] and Paraggio et al. [38] reported acetic acid production as a strain-dependent feature of this yeast. Other works have reported even lower values of acetic acid production by $T$. delbrueckii, ranging from 0.14 to $0.28 \mathrm{~g} / \mathrm{L}[4,14]$. T. delbrueckii is also a lower producer of acetaldehyde, in comparison with S. cerevisiae, which is an important advantage, since concentrations above $125 \mathrm{mg} / \mathrm{L}$ of acetaldehyde pertain to a negative effect on wine's flavor, often being described as oxidized. In red wines, acetaldehyde is, on the other hand, described as being of interest to produce vitisin B, a red stable phenol compound [4]. In fact, vitisin B belongs to the group of the most stable anthocyanins, which are normally used as a strategy to increase the intensity of wines' red color. Nevertheless, beyond this strategy, color perception can be increased through a reduction in the $\mathrm{pH}$ [5]. Regarding malic acid degradation, some contrasting reports characterize T. delbrueckii as consuming, for one side, between $20-25 \%$ of this acid [27,39], but on the other side as having no consumption at all [28]. Malic acid degradation seems to 
be, in this way, a strain-dependent feature, as also concluded by Du Plessis et al. [40]. In a similar way to malic acid, citric acid is an organic acid produced through the Tricarboxylic Acid Cycle (TCA) pathway, standing out as a pleasant citrus-like taste contributor to wines' aroma profile. Liu et al. [41] carried out pure fermentation of T. delbrueckii and S. cerevisiae and observed similarities between both species in terms of production of this acid, reaching concentrations of $2.18-2.36 \mathrm{~g} / \mathrm{L}$ and $2.23 \mathrm{~g} / \mathrm{L}$, respectively.

Another favorable characteristic associated with the use of T. delbrueckii is its higher production of succinic acid, in comparison with $S$. cerevisiae, being able to reach concentrations above $1 \mathrm{~g} / \mathrm{L}$ depending on the oxygen availability during fermentation [41,42]. In fact, Puertas et al. [43] reported productions by T. delbrueckii between $0.84 \mathrm{~g} / \mathrm{L}$ and $1.11 \mathrm{~g} / \mathrm{L}$, while in the same study $S$. cerevisiae only reached maximum values of $0.65 \mathrm{~g} / \mathrm{L}$. However, Franco-Duarte et al. [44] obtained maximum concentrations of $1.13 \mathrm{~g} / \mathrm{L}$ using natural isolates of S. cerevisiae. Alongside, in comparison with S. cerevisiae, T. delbrueckii generates amounts of mannoproteins up to $25 \%$ higher (expressed as mannose concentration) that are released from the yeast cell during alcoholic fermentation and during the ageing processes, and contribute to the chemical stabilization of white wines [4,5]. A similar study was performed by Domizio et al. [45], where T. delbrueckii revealed up to 50\% more polysaccharides, in pure fermentations, than the S. cerevisiae controls.

Oenological importance of glycerol stands out by its enhancement of softness and viscosity of wine [4,5]. Wines fermented by non-Saccharomyces yeasts, particularly T. delbrueckii, are recognized to result in slightly higher glycerol yields than those fermented by $S$. cerevisiae, in concentrations ranging between $1 \mathrm{~g} / \mathrm{L}$ [46] and $10.5 \mathrm{~g} / \mathrm{L}$ [47] for T. delbrueckii, while $S$. cerevisiae revealed maximum concentrations of $9.1 \mathrm{~g} / \mathrm{L}$ (depending on the wine style). Beyond glycerol production, T. delbrueckii is usually described as a low ethanol producer (40.6-72.7 g/L [48]) in comparison to traditional fermentations carried out by S. cerevisiae [4,7]. These concentrations are in a much lower range of values than the one obtained with S. cerevisiae strains-103 to $121 \mathrm{~g} / \mathrm{L}$ [49]. In addition, the great mouthfeel traits [14] reinforce the wide potential of $T$. delbrueckii in winemaking $[7,28,50]$. Table 1 reviews experimental results obtained regarding the most relevant fermentation parameters towards wines' organoleptic profile, comparing T. delbrueckii and S. cerevisiae.

Table 1. Comparison between Torulaspora delbrueckii and Saccharomyces cerevisiae concerning fermentation parameters quantified at the end of fermentation process with relevance in wine organoleptic profiles.

\begin{tabular}{|c|c|c|c|c|}
\hline Product & $\begin{array}{l}\text { Torulaspora } \\
\text { Delbrueckii }\end{array}$ & $\begin{array}{c}\text { Saccharomyces } \\
\text { Cerevisiae }\end{array}$ & Notes & References \\
\hline Acetic acid & $0.27-0.56 \mathrm{~g} / \mathrm{L}$ & $1.0-1.17 \mathrm{~g} / \mathrm{L}$ & Key signature in volatile acidity of wines & {$[14,20]$} \\
\hline Malic acid & $\begin{array}{l}\text { Consumption } \\
\text { between } 10.5-25 \%\end{array}$ & & $\begin{array}{c}\text { Whether degradation or } \\
\text { production is desirable depends on the } \\
\text { must characteristics. }\end{array}$ & {$[23,39,48]$} \\
\hline Citric acid & $2.18-2.36 \mathrm{~g} / \mathrm{L}$ & $2.23 \mathrm{~g} / \mathrm{L}$ & Citrus-like taste & [41] \\
\hline \multirow{2}{*}{ Succinic acid } & $0.84-1.11 \mathrm{~g} / \mathrm{L}$ & $\begin{array}{c}\text { Maximum of } \\
0.65 \mathrm{~g} / \mathrm{L}\end{array}$ & \multirow{2}{*}{$\begin{array}{c}\text { Minor acid in the overall wine acidity, although the } \\
\text { combination with one } \\
\text { molecule of ethanol creates the ester mono-ethyl } \\
\text { succinate, responsible for a mild, fruity aroma }\end{array}$} & [43] \\
\hline & - & $\begin{array}{l}\text { Maximum of } \\
1.13 \mathrm{~g} / \mathrm{L}\end{array}$ & & [44] \\
\hline Mannoproteins & \multicolumn{2}{|c|}{$\begin{array}{l}\text { T. delbrueckii produces } 25 \% \text { more than } \\
\text { S. cerevisiae }\end{array}$} & Released during fermentation or ageing processes & [23] \\
\hline Polysaccharides & \multicolumn{2}{|c|}{$\begin{array}{l}\text { T. delbrueckii releases } 50 \% \text { more than } \\
\text { S. cerevisiae }\end{array}$} & Increases the quality of mouthfeel properties & [45] \\
\hline Glycerol & $1-10.5 \mathrm{~g} / \mathrm{L}$ & $\begin{array}{l}\text { Maximum of } \\
9.1 \mathrm{~g} / \mathrm{L}\end{array}$ & Smoothness and viscosity features & {$[46,47]$} \\
\hline Ethanol & $40.6-72.68 \mathrm{~g} / \mathrm{L}$ & $103-121 \mathrm{~g} / \mathrm{L}$ & & {$[48,49]$} \\
\hline
\end{tabular}


Regarding higher alcohols, several authors presented contradictory results related to high and low levels of these compounds as produced by $T$. delbrueckii $[2,23,51]$, leading to conclude that this characteristic is, once again, strain-dependent. Particularizing for nitrogen metabolism, Bely et al. [14] observed higher residual nitrogen levels in pure fermentation with $T$. delbrueckii, in comparison to those obtained with S. cerevisiae alone. This discrepancy may be due to the fact that this species is less demanding for amino acids.

\section{Biotechnological Importance of T. delbrueckii}

\subsection{Bread Industry}

Bread making is a practice that has long been discovered and has been the subject of much progress. In more recent years, developments in bread making have been increasingly focused on the enhancement and diversification of the sensory pleasures of taste, texture, and appearance of the final product [19]. The degradation of the dough carbohydrates (namely fructose, glucose, sucrose and maltose) present in the flour, or even wittingly added, is carried out by yeasts, resulting in the release of carbon dioxide and ethanol, produced through glycolysis and posterior pyruvate decarboxylation and reduction $[17,19,30]$. Carbon dioxide is responsible for the dough leavening, while most of the ethanol evaporates during the baking process. However, the latter also plays an important role in the properties of the dough [17]. The choice of the appropriate yeast is usually based on (i) good fermentative power which could be translated into its ability to leaven the dough; (ii) capacity to use different carbon sources; and (iii) tolerance to stressful conditions, namely, osmotic, and freezing stresses $[30,52,53]$. S. cerevisiae strains have been domesticated and optimized for baking applications and are usually the manufacturer's required yeast for the baking industry. This species efficiently uses maltose as a source of energy, as opposed to Candida humilis and Kazachstania exigua which, according to de Vuyst et al. [17], are sourdough-specific maltose-negative yeasts. S. cerevisiae is commonly implemented as a leavening agent, becoming an alternative to sourdough (extensively used for years) particularly in rapid and industrial-scale bread productions [17]. However, T. delbrueckii is being pointed out as an alternative to S. cerevisiae in this industry, mainly due to its high osmotic and freeze-thawing resistance, showing improvement of the quality of the bakery products [29,30]. Experiments conducted by Almeida and Pais [29] demonstrated greater leavening activity in lean and frozen dough for T. delbrueckii strains, comparing to $S$. cerevisiae, as the traditional yeast was more prone to suffer from freeze damage during the storage of the doughs. Apart from this feature, T. delbrueckii strains displayed rapid growth, a more rapid response when exposed to hyperosmotic conditions, and high biomass production accompanied with sweet properties (associated with the release of aromatic compounds). These observations were later confirmed by HernandezLopez, Prieto and Randez-Gil [54]. Due to its osmotolerant properties, T. delbrueckii has already been used in the bakery industry in Japan, for the production of sweet breads and pastries [55].

Co-cultures using S. cerevisiae and T. delbrueckii species enhanced bread quality with superior aroma and improved sensorial attributes, with 47 volatile compounds-predominately alcohols, aldehydes, and esters - being identified in the bread crumb leavened with both yeasts [19]. Wahyono et al. [19] highlighted some properties of the resulting mixed bread which, using a radar plot, rated within a range of 4.73-5.57 from a total of 7 points, such as acceptability, enhanced flavor, mouthfeel, and color, in comparison with S. cerevisiae single cultures, which recorded within 4.07-5.71 range in the same radar plot.

\subsection{Production of Fermented Beverages}

In recent years, researchers worldwide have been paying particular attention to T. delbrueckii exploitation to improve wines organoleptic final profile and quality. As referred above, its physiological and metabolic properties revealed positive effects in wines characteristics towards acids and sugar consumption, but also an enhancement of the aroma complexity through the production of important metabolites [2-4,23,56-59]. During 
wine fermentation, higher alcohols (also termed fused alcohols) and esters contribute 30 to $80 \%$ to the aroma profiles of wine, being the two most relevant groups of metabolites [59]. Isobutanol, phenyl ethanol and isoamyl alcohol are the main fusel alcohols reported to contribute to the wine's scent in concentrations ranging from $1.41 \mathrm{mg} / \mathrm{L}$ to $9.2 \mathrm{mg} / \mathrm{L}$ [60]. According to Ebeler [61], yields of this type of metabolites can achieve 140-420 mg/L, but concentrations over $300 \mathrm{mg} / \mathrm{L}$ contribute negatively to the aroma quality. Besides fusel alcohols, the aromatic matrix of wine is composed of esters, which are by-products of yeasts metabolism during malolactic fermentation, ageing and, most relevant in this context, alcoholic fermentation. These molecules reach maximum values when yeasts achieve the stationary growth phase [62], as its production by T. delbrueckii is a straindependent feature [60]. Two main esters classes are present in wine: the ethyl esters and the acetate esters. The contribution of the latter encompasses desirable floral and fruity sensory properties in wine, contributing about $75 \%$ to the flavor profile [60-62]. However, as stated in Belda et al. [62], wines holding concentrations of ethyl acetate higher than $90 \mathrm{mg} / \mathrm{L}$ are considered to be faulty. Other important metabolites are fatty acids, which are detected in alcoholic beverages as mainly straight-chain and saturated molecules, with palmitoleic acid considered the most relevant unsaturated fatty acid. Besides these, fatty acids with different chain lengths are part of the wine's matrix but prevail in small amounts, which makes them not so significant as the previous ones [61].

In order to respond to the consumers' demands for wines with low content of ethanol, alongside with obtaining innovative and differentiated wine's profiles, non-Saccharomyces yeasts stand out as the organisms per excellence to achieve a reduction in initial ethanol content by about $1-2 \%(v / v)$, having into account the used species and the conditions in which fermentations are performed [5]. Although the production of wines using T. delbrueckii cultures can be more expensive and time-consuming, in comparison to those produced with S. cerevisiae [33], the fermentation of grape juice with T. delbrueckii tends to originate wines with lower content of alcohol and, at the same time, with higher levels of glycerol. These properties are particularly advantageous for full-bodied and well-structured red wines, obtained from grapes with increased maturity [42,63]. Global warming is a concerning and alarming issue at different levels, also with regard to viniculture, since this situation has an impact on the accelerated ripening of grapes promoting a faster increase in their sugar content which, ultimately, result in the production of wines with increased alcohol content $[63,64]$. Thus, the search for new yeasts that completely consume sugars and have the ability to both decrease the final ethanol yields and increase the glycerol concentrations is imperative for the construction of organoleptically improved wines, as an alternative to the standardization of the food industry. The variation found between yeast strains plays a very important role to address this issue. In many cases, producers choose to mix different strains to improve the quality of the beverages, and to balance their aromatic and fermentative profile.

Co-cultures of T. delbrueckii and S. cerevisiae, in synthetic grape must medium show that from the moment $S$. cerevisiae is inoculated, the viability of $T$. delbrueckii decreases even if it is at higher concentrations than the former. This was confirmed by Taillandier et al. [65] who used an inoculum of T. delbrueckii twenty times higher than S. cerevisiae and observed growth inhibition of the first yeast. As a valid explanation of the phenomenon, the authors pointed to the possible metabolite release by $S$. cerevisiae, excluding substrate competition and cell-to-cell contact mechanism as probable causes. On the other hand, Azzolini et al. [3] demonstrated clear distinct aroma patterns of sequential fermentations of T. delbrueckii and S. cerevisiae, and of S. cerevisiae individual inoculations. The authors detected (i) improvements in the analytical profile and flavor complexity of wines; (ii) freshness and acidity sensory features; (iii) floral and more differentiated wines. Thus, the introduction of non-Saccharomyces species in the manufacturing of wines is a useful tool to modulate the organoleptic profile of wines and include innovative and differentiated styles compared to the standardized wines already present in the market. 
The dominance ratio of $\mathrm{T}$. delbrueckii when inoculated in fresh must depends on numerous factors, from the inoculum size, quantity, and type of viable wild microorganism initially present in the must, fermentation stage, sugar and ethanol concentrations, killer and killer sensitivity phenotype of the inoculated yeast, the concentration of $\mathrm{SO}_{2}$ and copper, pesticides potentially present in grapes, among many other [12]. As a result, under the conditions usually present in grape must fermentations, T. delbrueckii initial population growth is high, becoming a protagonist at an earlier stage of the process [23]. Since sugar-rich musts originate high levels of ethanol, in the latter stages, slower fermentation rates and increased cell death of this yeast are observed, probably as a result of its lower resistance to high ethanol concentrations in comparison with S. cerevisiae and of its higher hexose transport sensitivity [31]. As a consequence, the process may cease prematurely or become sluggish unless a more resistant yeast is added in a co-inoculation or sequential process, as aforementioned [15].

In addition to wine, T. delbrueckii can be explored in the dynamics of other beverages. One example with a great economic value and one of the most popular drinks around the world is beer. The wort ingredients-composed of malted cereals, hops, and fresh water-are transformed not only in alcohol but additionally into organoleptic compounds released by the yeasts, such as aldehydes, higher alcohols, esters, carbonyl compounds, organic acids, and terpenic substances, giving identity to the beer as the final product. However, just like wine, consumers have been switching from classic style beer to new beer-blended beverages as they look for innovative aroma palates. Since this can be achieved by using different yeast strains, the search for new yeasts, particularly in the non-Saccharomyces group including T. delbrueckii, has increased $[63,66,67]$. Three studies have reported the aromatic profile of beers influenced by the use of T. delbrueckii strains in the brewing process $[35,68,69]$. These yeasts displayed the ability to transform hop aroma terpenoids and enhance ethyl hexanoate and ethyl octanoate levels.

One particular application of T. delbrueckii, only superficially explored, is in the mezcal fermenting process. The use of this species in this process revealed an increase in the levels of $\beta$-fructofuranosidase enzymes with fructosyltransferase activity [70], and also high levels of phenyl acetate [71]. Similarly to other applications, mezcal fermentations benefits from a mixed inoculum of $S$. cerevisiae and T. delbrueckii, to obtain a balanced aromatic and fermentative profile. Furthermore, in cider production, monoculture fermentations using T. delbrueckii strains showed to produce more diverse volatile compounds than with S. cerevisiae strains [72]. In another study from 2019, Lorenzini et al. [73] tested several Saccharomyces and non-Saccharomyces yeasts for their capacity to ferment apple juice and to influence the volatile compound production in cider fermentations. Among non-Saccharomyces yeasts, T. delbrueckii was the greatest producer of ethyl decanoate and ethyl hexanoate, key aroma compounds in cider production, conferring fruity aromas.

The main fermented beverages in which T. delbrueckii is employed are reviewed in Table 2.

Table 2. Torulaspora delbrueckii's applications in fermented beverages.

\begin{tabular}{|c|c|c|c|c|}
\hline $\begin{array}{l}\text { Beverages } \\
\text { Applications }\end{array}$ & Used Substrate & Advantages & Disadvantages & References \\
\hline Beer & Wort & $\begin{array}{l}\text { High tolerance to hop compounds; good } \\
\text { flavor-forming properties }\end{array}$ & Low sugar utilization & {$[35,66,68,69]$} \\
\hline Mezcal & Agave juice $^{\dagger}$ & $\begin{array}{c}\text { Rich in volatile compounds; acceptable in } \\
\text { sensory tests }\end{array}$ & Low performance & {$[67,70,71]$} \\
\hline Tequila & Agave juice * & Positive influence on the final sensory profile & - & [74] \\
\hline Cider & Apple juice ${ }^{\dagger}$ & $\begin{array}{c}\text { Great production of ethyl decanoate and } \\
\text { ethyl hexanoate }\end{array}$ & $\begin{array}{l}\text { Low performance; } \\
\text { negligible amounts of } \\
\text { acetate esters }\end{array}$ & {$[72,73]$} \\
\hline Mead & Honey sugar & Good fermentation ability; Good sensory features & Grassy flavor & [7] \\
\hline $\begin{array}{l}\text { Soy alcoholic } \\
\text { beverage }\end{array}$ & Soy whey & $\begin{array}{c}\text { Enrich aroma profiles: high levels of ethyl } \\
\text { decanoate and ethyl hexanoate; metabolize } \\
\text { hexanal; }\end{array}$ & - & [75] \\
\hline
\end{tabular}

${ }^{*}$ Specifically from Agave tequilana; ${ }^{\dagger}$ sterile. 


\subsection{Other Food Applications}

The reported versatility of $T$. delbrueckii makes it a remarkable asset to be explored, not only for bread and fermented beverages purposes, but also in other diverse food products (Table 3). One example is the production of chocolate in which yeasts play a key role in flavour development, as the quality of chocolate is reduced if the cocoa fermentation process is conducted without these microorganisms [76]. This importance is reinforced by Visitin et al. [77] by showing the involvement of T. delbrueckii in the fermentation of cocoa beans (Theobroma cacao [76]) to produce chocolate, despite not yet being standard in this industry. Authors showed that through a combination with S. cerevisiae, modifications on the analytical profile of the chocolate are obtained. Moreover, differences in the samples obtained from S. cerevisiae and T. delbrueckii inoculated chocolate had a significant impact on the consumers' perception of the final product, mentioned by some as fruitier. Therefore, the use of this unconventional yeast resulted in a positive contribution to the development of the chocolate's final aroma. In addition, T. delbrueckii can also be explored in the cheese industry, benefiting from its tolerance to low temperatures, low $\mathrm{pH}$, high salt concentrations and low water activity [78]. Andrade et al. [79] produced cheese from fermented milk, with the aim of evaluating the impact of $T$. delbrueckii (in mixed or pure inocula) on cheese production, detecting a slow consumption of lactose which can be translated into a reduced $\beta$-galactosidase activity, as stated by the authors.

Table 3. T. delbrueckii industrial food applications.

\begin{tabular}{|c|c|c|c|c|}
\hline Food Applications & Used Substrate & Advantages & Disadvantages & References \\
\hline Chocolate & Cocoa beans & $\begin{array}{l}\text { Good flavor quality of cocoa and, } \\
\text { therefore, the chocolate }\end{array}$ & $\begin{array}{l}\text { Expedite in mixed fermentations } \\
\text { with S. cerevisiae }\end{array}$ & [77] \\
\hline Cheese & Cheese & Varied aromatic properties & $\begin{array}{c}\text { Unable to inhibit pathogenic } \\
\text { bacteria; low } \\
\beta \text {-glucosidase activity }\end{array}$ & {$[79,80]$} \\
\hline Honey & Honey sugar & Rapidly ferment sugar & $\begin{array}{l}\text { Large-scale productions only in } \\
\text { combination with S. cerevisiae }\end{array}$ & [7] \\
\hline Olive oil & Black olives & Easy hydrolyzation of olive oil & $\begin{array}{l}\text { Growth inhibition at } \\
\text { concentrations higher than } 0.5 \% \\
(w / v) \text { of oleuropein }\end{array}$ & [81] \\
\hline Coffee & Coffee cherries & Improve coffee's sensorial quality & $\begin{array}{c}\text { Pronounced astringency } \\
\text { depending on the coffee variety }\end{array}$ & {$[82,83]$} \\
\hline Bio-protection & - & $\begin{array}{l}\text { Reduction in the use of chemical } \\
\text { preservatives to control } \\
\text { food spoilage }\end{array}$ & - & {$[50,84]$} \\
\hline
\end{tabular}

Another highly sought product in the food market is honey. This is produced by honeybees (namely Apis mellifera) and is a natural source of fermentable sugar ready to be used by fermentative yeasts [7]. Barry et al. [7] were able to isolate two T. delbrueckii strains directly from the microbiome of a honeybee and use them to ferment honey, obtaining interesting results to be applied at an industrial scale, especially when in combination with a S. cerevisiae champagne strain. The list of applications of T. delbrueckii can be extended also to the fermentation of olives, with Psani and Kotzekidou [81] reporting good outcomes from the exploitation of this species, such as being able to hydrolyse olive oil and tributyrin, alongside the capacity of T. delbrueckii cultures to inhibit foodborne pathogens such as Listeria monocytogenes, Bacillus cereus, and Salmonella typhimurium. However, the authors also detected a strong growth inhibition of T. delbrueckii by the assimilation of oleuropein at yields greater than $0.5 \%(w / v)$. T. delbrueckii can also be employed in the fermentation of coffee beans, one of the most popular consumed beverages. Coffee fermentation occurs naturally, however, the use of yeast as a starter culture was shown to improve coffee flavour and aroma. Da Mota et al. [82] showed that T. delbrueckii inoculation exhibited the best performance in natural coffee compared to $S$. cerevisiae and to the control (without inoculation), by positively improving the sensorial quality of the final product. Nevertheless, other 
authors also reported that the performance of T. delbrueckii may vary according to coffee varieties, production regions, processing methods, and microbial species naturally present in the fruit [83-85]. In general, the use of T. delbrueckii during coffee fermentation can result in coffees with distinct aromas and flavours that increase the possibility of producing speciality coffees, adding value to the product. In addition to the food applications mentioned so far, the yeast T. delbrueckii has also been proposed as a biocontrol agent against spoilage organisms improving the product quality and reducing the use of chemical preservatives to control food spoilage. Simonin et al. [50] reported the successful implantation of the T. delbrueckii strain as an alternative to sulphiting without compromising the fermentation kinetics in two Burgundian wineries. Furthermore, Al-Qaysi et al. [4] also revealed a high inhibitory effect of T. delbrueckii against the plant pathogens Fusarium oxysporium, Sclerotinia sclerotiorum, and Macrophomina phaseolina, inhibiting mycelial growth in $55.3 \%, 66.2 \%$, and $31.11 \%$, respectively.

\section{Genetic Tools Employed towards T. delbrueckii Improvement}

The prompt progress of genetics, engineering and biology fields enhanced the continuous search for yeasts with improved traits and phenotypes in order to expand their abilities to be further implemented in the most diverse research areas or likewise for commercialization. Yeasts are an advantageous research model due to the easiness with which genes can be manipulated, in particular, recurring deletions, insertions or modifications under controlled conditions. The combination of classical genetic approaches, transformation methods, and DNA sequencing techniques have helped in the molecular characterization of yeasts over the years. In order to apply these techniques, a deep understanding of yeast's biological diversity is mandatory, to explore the different metabolic pathways and to incorporate the great degree of biological inter-strain diversity.

Regarding genetic tools development to manipulate T. delbrueckii strains, already in 1989, Compagno et al. [86] showed for the first time that a $2 \mu \mathrm{m}$ vector could be maintained and replicated in T. delbrueckii. Later on, the discovery of an endogenous circular plasmid pTD1 (4.8 kbp) from T. delbrueckii strain CBS1090 was reported [78]. Over the past few years, several attempts successfully identified, cloned, deleted or expressed several genes in T. delbrueckii [87-91]. This knowledge opened the way to the improvement of T. delbrueckii metabolism and to the development of new genetic tools. In recent years, CRISPR/Cas9 (Clustered Regularly Interspaced Short Palindromic Repeats/associated protein 9) revolutionized research as a gene-based editing mechanism allowing the selective manipulation of DNA [92,93]. Although there is yet no current employment of CRISPR towards T. delbrueckii, this engineering tool has been extensively used for other non-conventional yeasts such as Yarrowia lipolytica, Pichia pastoris, Komagataella phaffii, Kluyveromyces lactis, Kluyveromyces marxianus [94], Schizosaccharomyces pombe, Candida albicans and Candida glabrata, and for the conventional yeast $S$. cerevisiae [92-97].

Besides the versatility of $T$. delbrueckii species, some limitations have been hampering its wide biotechnological use, such as the limited ethanol resistance of some strains during wine fermentation, which ranges from $7.4 \%(v / v)$ [14] to $9 \%(v / v)$ [36], in addition to the fact that Belda et al. [27] indicate decreases of cells viability already when ethanol levels exceed $8 \%(v / v)$. In this context, some strategies have been proposed in this species in order to improve phenotypes with a biotechnological impact, such as random mutagenesis, sexual hybridization, bioprospecting and metabolic engineering $[67,96]$ to expand the boundaries of T. delbrueckii's biotechnological use. The use of Genetically Modified Organisms (GMOs) involves a certain ambiguity and divergence of opinions, and their implementation relies on the legislation in force in each country [97,98]. Currently, the unacceptance of the use of GMOs by the International Organization of Vine and Wine (OIV) makes the products obtained by New Genomic Techniques (NGTs), such as CRISP, unsuitable for commercialization in the European Union (EU) $[99,100]$. In the EU, Regulation (EC) No. 1829/2003 (article 1) and Regulation No. 1830/2003 on genetically modified food aim to ensure the achievement of a high level of protection to environmental, human, and 
animal health, alongside the tracing and labelling of genetically modified products, respectively. Although the Directive 2001/18/EC (in particular, article 23) allows the Member States to deliberate whether they restrict or prohibit the cultivation of genetically modified crops in their territory, in 2018, the European Court of Justice clarified that organisms modified by site-directed mutagenesis like CRISPR would be included in the definition of a GMO [101]. On the other hand, the United States has no specific federal law aimed at regulating GMOs, with the country being considered a major developer and marketer of genetically modified crops [102-104]. Only two registered and approved genetically modified wine yeasts are currently used in Canada, the USA, and Moldova [105-107].

In this context, adaptive laboratory evolution (ALE) emerges as a successful nongenetically modified approach to improve yeast features. According to Dragosits and Mattanovich [108], ALE stands as a powerful tool to study the evolutionary phenomena occurring in microorganisms in controlled laboratory environments, being already performed 100 years ago by William Dallinger. However, these sorts of studies have been explored frequently only in the past 25 years, employing S. cerevisiae and Escherichia coli as the main models. ALE helps to gain insight into the basic molecular evolution mechanisms where microorganisms are usually inoculated for long-term adaptation (lasting for weeks or months) under specific selective stress conditions [108]. During the design of ALE experiments, several parameters need to be taken into account such as (i) the genetic diversity sources, which includes natural mutations, UV or chemical mutagenesis, or mating; (ii) the selective pressure that could be constant, increased or intermittent over time; and (iii) the cultivation strategies which can be diverse but the most used ones are batch cultivations (performed as sequential serial transfers) or continuous cultures (where the conditions are kept constant and the limitation of one nutritional component is standard) [108]. When exposed to these environments, different types of mutations are identified, such as single-nucleotide polymorphisms (SNPs), transposable elements, small scale insertions and deletions (indels), large scale amplifications or deletions, which contribute to certain changes at the gene regulation and fitness levels, giving rise to improved phenotypes [108]. Several studies performing adaptive evolution for S. cerevisiae and focusing on nutritional adaptation, reported increased biomass yields and decreased fermentative performance in glucoselimited selection environments [108,109]. Jansen et al. [110] also observed modifications in the morphology of the cells, alongside with higher affinity for glucose. Regarding stress limitations, Dhar et al. [111] described that increases in salt tolerance by ALE were related to increases in the genome size and changes in the expression of several genes. Other studies focused on improvements of ethanol tolerance by S. cerevisiae, have detected a higher behavioral variability of the evolved clones in comparison with the parental strain, when levels of ethanol in the medium were increased from 6 to $8 \%(v / v)$ [112], as well as higher osmotic and temperature tolerances, in comparison with the original strain [113]. Avrahami-Moyal et al. [114] suggested that the stability of the cell wall is an essential factor, and that mutations in the translational regulator SSD1 and UTH1 are responsible for the ethanol tolerance of this species. This type of study benefits from the wide inter- and even intra-strain diversity observed, manifested also in genomic differences during the maintenance of microbial cultures in different environmental conditions, and associated with adaptive microevolutionary changes observed even within the descendants of the same strain [115]. When considering K. marxianus, strains with higher growth rates were obtained under stressful high ethanol environments [116], within the range of 7-10\% $(v / v)$ of ethanol [117]. In a similar way, a recent study and, to the extent of our knowledge, the only report applying this technique to the generation of $T$. delbrueckii evolved strains, was conducted by Catrielo et al. [96]. The authors efficiently obtained evolved clones of $T$. delbrueckii with improved growth kinetic parameters, increased ethanol resistance, variants capable of tolerating ethanol concentrations of $11.5 \%(v / v)$, and additional higher resistance to $\mathrm{SO}_{2}$, in comparison with the original strain. In addition to these features, co-inoculations with the evolved T. delbrueckii and S. cerevisiae clones were performed, evidencing improved contribution effects to the aromatic profile of wine, with particular 
emphasis to 2-ethylhexanol, total alcohol levels, total aldehydes, total sulphur compounds and total phenolic derivates with significant differences to the control fermentation, designated only by $S$. cerevisiae evolved clone. Besides this parameter, other studies conducted with $S$. cerevisiae model reported increases in copper resistance mediated by increased expression of CUP1, and decreased levels of the transporters CTR2 and CCC2 in the evolved strain, together with lower activity of antioxidant enzymes [118].

\section{Conclusions}

S. cerevisiae is still the yeast of choice in different biotechnological areas, namely in the wine and bakery industries. However, many studies have pointed out the great interest of T. delbrueckii for industrial exploitation. Now, a higher number of studies are necessary to assess the phenotypic, metabolic and genomic landscape of this species, and, especially, to address strain similarities/dissimilarities with great importance to allow its more extensive and rational exploitation, as detailed in this review. With advances recently obtained in the genome characterization and annotation of T. delbrueckii, the elucidation of the molecular bases that underlay this species' specific traits will start to be revealed. This will allow researchers to highlight particular advantages of this species that have caught the attention of the bread and wine industries, and to overcome problems that make it less advantageous in relation to $S$. cerevisiae.

Author Contributions: Writing—original draft preparation, T.F., F.S.-S., F.P., R.F.-D., M.J.S.; Methodology, T.R., P.S., R.F.-D.; Writing-review and editing, T.F., F.S.-S., F.P., T.R., P.S., R.F.-D., M.J.S. All authors have read and agreed to the published version of the manuscript.

Funding: This work was supported by the UID/BIA/04050/2013 (POCI-01-0145-FEDER-007569) and UID/BIA/04050/2019 strategic programs and by the project PTDC/BIA-MIC/32059/2017, which is funded by national funds through the FCT-Fundação para a Ciência e Tecnologia and by the ERDF- European Regional Development Fund through the COMPETE2020-Programa Operacional Competitividade e Internacionalização (POCI) and Sistema de Apoio à Investigação Científica e Tecnológica (SAICT). FS-S was supported by a Fellowship (UI/BD/150873/2021) from Fundação para a Ciência e Tecnologia, Portugal.

Institutional Review Board Statement: Not applicable.

Informed Consent Statement: Not applicable.

Conflicts of Interest: The authors declare no conflict of interest.

\section{References}

1. Drumonde-Neves, J.; Fernandes, T.; Lima, T.; Pais, C.; Franco-Duarte, R. Learning from 80 years of studies: A comprehensive catalogue of non-Saccharomyces yeasts associated with viticulture and winemaking. FEMS Yeast Res. 2021, 21, foab017. [CrossRef]

2. Kosel, J.; Čadež, N.; Schuller, D.; Carreto, L.; Franco-Duarte, R.; Raspor, P. The influence of Dekkera bruxellensis on the transcriptome of Saccharomyces cerevisiae and on the aromatic profile of synthetic wine must. FEMS Yeast Res. 2017, 17, 1-11. [CrossRef]

3. Azzolini, M.; Tosi, E.; Lorenzini, M.; Finato, F.; Zapparoli, G. Contribution to the aroma of white wines by controlled Torulaspora delbrueckii cultures in association with Saccharomyces cerevisiae. World J. Microbiol. Biotechnol. 2015, 31, 277-293. [CrossRef]

4. Benito, S. The impact of Torulaspora delbrueckii yeast in winemaking. Appl. Microbiol. Biotechnol. 2018, 102, 3081-3094. [CrossRef] [PubMed]

5. Benito, Á.; Calderón, F.; Benito, S. The influence of non-Saccharomyces species on wine fermentation quality parameters. Fermentation 2019, 5, 54. [CrossRef]

6. Albertin, W.; Chasseriaud, L.; Comte, G.; Panfili, A.; Delcamp, A.; Salin, F.; Marullo, P.; Bely, M. Winemaking and bioprocesses strongly shaped the genetic diversity of the ubiquitous yeast Torulaspora delbrueckii. PLoS ONE 2014, 9, e94246. [CrossRef]

7. Barry, J.P.; Metz, M.S.; Hughey, J.; Quirk, A.; Bochman, M.L. Two Novel Strains of Torulaspora delbrueckii isolated from the honey bee microbiome and their use in honey fermentation. Fermentation 2018, 4, 22. [CrossRef]

8. Nguyen, N.H.; Suh, S.O.; Blackwell, M. Five novel Candida species in insect-associated yeast clades isolated from Neuroptera and other insects. Mycologia 2007, 99, 842-858. [CrossRef] [PubMed]

9. Capriotti, A. Torulaspora nilssoni nov. spec. Arch. Für Mikrobiol. 1957, 28, 247-254. [CrossRef]

10. Byzov, B.A.; Thanh, V.N.; Babjeva, I.P. Yeasts associated with soil invertebrates. Biol. Fertil. Soils 1993, 16, 183-187. [CrossRef]

11. Limtong, S.; Koowadjanakul, N. Yeasts from phylloplane and their capability to produce indole-3-acetic acid. World J. Microbiol. Biotechnol. 2012, 28, 3323-3335. [CrossRef] [PubMed] 
12. Yurkov, A.M.; Chernov, I.Y. Geographical races of certain species of ascomycetous yeasts in the Moscow and Novosibirsk regions. Microbiology 2005, 74, 597-601. [CrossRef]

13. Silva-Bedoya, L.M.; Ramirez-Castrillon, M.; Osorio-Cadavid, E. Yeast diversity associated to sediments and water from two Colombian artificial lakes. Braz. J. Microbiol. 2014, 45, 135-142. [CrossRef] [PubMed]

14. Bely, M.; Stoeckle, P.; Masneuf-Pomarède, I.; Dubourdieu, D. Impact of mixed Torulaspora delbrueckii-Saccharomyces cerevisiae on high-sugar fermentation. Int. J. Food Microbiol. 2008, 122, 312-320. [CrossRef] [PubMed]

15. Renault, P.; Coulon, J.; de Revel, G.; Barbe, J.C.; Bely, M. Increase of fruity aroma during mixed T. delbrueckii/S. cerevisiae wine fermentation is linked to specific esters enhancement. Int. J. Food Microbiol. 2015, 207, 40-48. [CrossRef]

16. Kaygusuz, I.; Mulazimoglu, L.; Cerikcioglu, N.; Toprak, A.; Oktay, A.; Korten, V. An unusual native tricuspid valve endocarditis caused by Candida colliculosa. Clin. Microbiol. Infect. 2003, 9, 319-322. [CrossRef] [PubMed]

17. De Vuyst, L.; Harth, H.; Van Kerrebroeck, S.; Leroy, F. Yeast diversity of sourdoughs and associated metabolic properties and functionalities. Int. J. Food Microbiol. 2016, 239, 26-34. [CrossRef]

18. Hendriks, L.; Goris, A.; Van De Peer, Y.; Neefs, J.M.; Vancanneyt, M.; Kersters, K.; Berny, J.F.; Hennebert, G.L.; De Wachter, R. Phylogenetic Relationships among Ascomycetes and Ascomycete-like Yeasts as Deduced from Small Ribosomal Subunit RNA Sequences. Syst. Appl. Microbiol. 1992, 15, 98-104. [CrossRef]

19. Wahyono, A.; Lee, S.B.; Kang, W.W.; Park, H.D. Improving bread quality using co-cultures of Saccharomyces cerevisiae, Torulaspora delbrueckii JK08, and Pichia anomalia JK04. Ital. J. Food Sci. 2016, 28, 298-313. [CrossRef]

20. Ramírez, M.; Velázquez, R. The yeast Torulaspora delbrueckii: An interesting but difficult-to-use tool for winemaking. Fermentation 2018, 4, 94. [CrossRef]

21. Saluja, P.; Yelchuri, R.K.; Sohal, S.K.; Bhagat, G.; Prasad, G.S. Torulaspora indica a novel yeast species isolated from coal mine soils. Antonie Van Leeuwenhoek 2012, 101, 733-742. [CrossRef] [PubMed]

22. Ramírez, M.; Ambrona, J. Construction of sterile ime1 $\Delta$-transgenic Saccharomyces cerevisiae wine yeasts unable to disseminate in nature. Appl. Environ. Microbiol. 2008, 74, 2129-2134. [CrossRef]

23. Cherry, J.M.; Hong, E.L.; Amundsen, C.; Balakrishnan, R.; Binkley, G.; Chan, E.T.; Christie, K.R.; Costanzo, M.C.; Dwight, S.S.; Engel, S.R.; et al. Saccharomyces Genome Database: The genomics resource of budding yeast. Nucleic Acids Res. 2012, 40, D700-D705. [CrossRef]

24. Gordon, J.L.; Armisen, D.; Proux-We'ra, E.; ÓhEígeartaigh, S.S.; Byrne, K.P.; Wolfe, K.H. Evolutionary Erosion of Yeast Sex Chromosomes by Mating-Type Switching Accidents. Proc. Natl. Acad. Sci. USA 2011, 108, 20024-20029. [CrossRef]

25. Santiago, C.; Rito, T.; Vieira, D.; Fernandes, T.; Pais, C.; Sousa, M.J.; Soares, P.; Franco-Duarte, R. Improvement of Torulaspora delbrueckii genome annotation: Towards the exploitation of genomic features of a biotechnologically relevant yeast. J. Fungi 2021, 7, 287. [CrossRef] [PubMed]

26. Shen, X.X.; Opulente, D.A.; Kominek, J.; Zhou, X.; Steenwyk, J.L.; Buh, K.V.; Haase, M.A.; Wisecaver, J.H.; Wang, M.; Doering, D.T.; et al. Tempo and mode of genome evolution in the budding yeast subphylum. Cell 2018, 175, 1533-1545. [CrossRef] [PubMed]

27. Belda, I.; Navascués, E.; Marquina, D.; Santos, A.; Calderon, F.; Benito, S. Dynamic analysis of physiological properties of Torulaspora delbrueckii in wine fermentations and its incidence on wine quality. Appl. Microbiol. Biotechnol. 2015, 99, 1911-1922. [CrossRef] [PubMed]

28. Loira, I.; Vejarano, R.; Bañuelos, M.A.; Morata, A.; Tesfaye, W.; Uthurry, C.; Villa, A.; Cintora, I.; Suárez-Lepe, J.A. Influence of sequential fermentation with Torulaspora delbrueckii and Saccharomyces cerevisiae on wine quality. LWT-Food Sci. Technol. 2014, 59, 915-922. [CrossRef]

29. Almeida, M.J.; Pais, C. Leavening ability and freeze tolerance of yeasts isolated from traditional corn and rye bread doughs. Appl. Environ. Microbiol. 1996, 62, 4401-4404. [CrossRef]

30. Pacheco, A.; Santos, J.; Chaves, S.; Almeida, J.; Leão, C.; Sousa, M.J. The Emerging Role of the Yeast Torulaspora delbrueckii in Bread and Wine Production: Using Genetic Manipulation to Study Molecular Basis of Physiological Responses. Struct. Funct. Food Eng. 2012, 339-370. [CrossRef]

31. Santos, J.; Sousa, M.J.; Cardoso, H.; Inacio, J.; Silva, S.; Spencer-Martins, I.; Leão, C. Ethanol tolerance of sugar transport, and the rectification of stuck wine fermentations. Microbiology 2008, 154, 422-430. [CrossRef] [PubMed]

32. Alves-Araújo, C.; Pacheco, A.; Almeida, M.J.; Spencer-Martins, I.; Leão, C.; Sousa, M.J. Sugar utilization patterns and respirofermentative metabolism in the baker's yeast Torulaspora delbrueckii. Microbiology 2007, 153, 898-904. [CrossRef] [PubMed]

33. Velázquez, R.; Zamora, E.; Álvarez, M.L.; Ramírez, M. Using Torulaspora delbrueckii killer yeasts in the elaboration of base wine and traditional sparkling wine. Int. J. Food Microbiol. 2019, 289, 134-144. [CrossRef] [PubMed]

34. Holm Hansen, E.; Nissen, P.; Sommer, P.; Nielsen, J.C.; Arneborg, N. The effect of oxygen on the survival of non-Saccharomyces yeasts during mixed culture fermentations of grape juice with Saccharomyces cerevisiae. J. Appl. Microbiol. 2001, 91, 541-547. [CrossRef]

35. Ciani, M.; Picciotti, G. The growth kinetics and fermentation behaviour of some non-Saccharomyces yeasts associated with winemaking. Biotechnol. Lett. 1995, 17, 1247-1250. [CrossRef]

36. Ciani, M.; Maccarelli, F. Oenological properties of non-Saccharomyces yeasts associated with winemaking. World J. Microbiol. Biotechnol. 1997, 14, 199-203. [CrossRef] 
37. King, A.; Dickinson, J.R. Biotransformation of monoterpene alcohols by Saccharomyces cerevisiae, Torulaspora delbrueckii and Kluyveromyces lactis. Yeast 2000, 16, 499-506. [CrossRef]

38. Paraggio, M.; Fiore, C. Screening of Saccharomyces cerevisiae wine strains for the production of acetic acid. World J. Microbiol. Biotechnol. 2004, 20, 743-747. [CrossRef]

39. Chen, K.; Escott, C.; Loira, I.; Del Fresno, J.M.; Morata, A.; Tesfaye, W.; Calderon, F.; Suárez-Lepe, J.A.; Han, S.; Benito, S. Use of non-Saccharomyces yeasts and oenological tannin in red winemaking: Influence on colour, aroma and sensorial properties of young wines. Food Microbiol. 2018, 69, 51-63. [CrossRef]

40. Du Plessis, H.W.; Du Toit, M.; Hoff, J.W.; Hart, R.S.; Ndimba, B.K.; Jolly, N.P. Characterisation of Non-Saccharomyces Yeasts Using Different Methodologies and Evaluation of their Compatibility with Malolac-tic Fermentation. South Afr. J. Enol. Vitic. 2017, 38 , 46-63. [CrossRef]

41. Liu, S.; Laaksonen, O.; Kortesniemi, M.; Kalpio, M.; Yang, B. Chemical composition of bilberry wine fermented with nonSaccharomyces yeasts (Torulaspora delbrueckii and Schizosaccharomyces pombe) and Saccharomyces cerevisiae in pure, sequential and mixed fermentations. Food Chem. 2018, 266, 262-274. [CrossRef]

42. Contreras, A.; Hidalgo, C.; Henschke, P.A.; Chambers, P.J.; Curtin, C.; Varela, C. Evaluation of non-Saccharomyces yeasts for the reduction of alcohol content in wine. Appl. Environ. Microbiol. 2014, 80, 1670-1678. [CrossRef]

43. Puertas, B.; Jiménez, M.J.; Cantos-Villar, E.; Cantorial, J.M.; Rodríguez, M.E. Use of Torulaspora delbrueckii and Saccharomyces cerevisiae in semi-industrial sequential inoculation to improve quality of Palomino and Chardonnay wines in warm climates. $J$. Appl. Microbiol. 2016, 122, 733-746. [CrossRef] [PubMed]

44. Franco-Duarte, R.; Bessa, D.; Gonçalves, F.; Martins, R.; Silva-Ferreira, A.C.; Schuller, D.; Sampaio, P.; Pais, C. Genomic and transcriptomic analysis of Saccharomyces cerevisiae isolates with focus in succinic acid production. FEMS Yeast Res. 2017, 17, 1-12. [CrossRef] [PubMed]

45. Domizio, P.; Liu, Y.; Bisson, L.F.; Barile, D. Use of non-Saccharomyces wine yeasts as novel sources of mannoproteins in wine. Food Microbiol. 2014, 43, 5-15. [CrossRef] [PubMed]

46. Escribano, R.; González-Arenzana, L.; Portu, J.; Garijo, P.; López-Alfaro, I.; López, R.; Santamaria, P.; Gutiérrez, A.R. Wine aromatic compound production and fermentative behaviour within different non-Saccharomyces species and clones. J. Appl. Microbiol. 2018, 124, 1521-1531. [CrossRef] [PubMed]

47. Ivit, N.N.; Longo, R.; Kemp, B. The Effect of Non-Saccharomyces and Saccharomyces Non-cerevisiae Yeasts on Ethanol and Glycerol Levels in Wine. Fermentation 2020, 6, 77. [CrossRef]

48. Mecca, D.; Benito, S.; Beisert, B.; Brezina, S.; Fritsch, S.; Semmler, H.; Rauhut, D. Influence of nutrient supplementation on Torulaspora delbrueckii wine fermentation aroma. Fermentation 2020, 6, 35. [CrossRef]

49. Franco-Duarte, R.; Umek, L.; Mendes, I.; Castro, C.C.; Fonseca, N.; Martins, R.; Silva-Ferreira, A.C.; Sampaio, P.; Pais, C.; Schuller, D. New integrative computational approaches unveil the Saccharomyces cerevisiae pheno-metabolomic fermentative profile and allow strain selection for winemaking. Food Chem. 2016, 211, 509-520. [CrossRef]

50. Simonin, S.; Alexandre, H.; Nikolantonaki, M.; Coelho, C.; Tourdot-Maréchal, R. Inoculation of Torulaspora delbrueckii as a bio-protection agent in winemaking. Food Res. Int. 2018, 107, 451-461. [CrossRef]

51. Comitini, F.; Gobbi, M.; Domizio, P.; Romani, C.; Lencioni, L.; Mannazzu, I.; Ciani, M. Selected non-Saccharomyces wine yeasts in controlled multistarter fermentations with Saccharomyces cerevisiae. Food Microbiol. 2011, 28, 873-882. [CrossRef]

52. Alves-Araújo, C.; Almeida, M.J.; Sousa, M.J.; Leão, C. Freeze tolerance of the yeast Torulaspora delbrueckii: Cellular and biochemical basis. FEMS Microbiol. Lett. 2004, 240, 7-14. [CrossRef]

53. Li, Z.; Li, H.; Bian, K. Microbiological characterization of traditional dough fermentation starter (Jiaozi) for steamed bread making by culture-dependent and culture-independent methods. Int. J. Food Microbiol. 2016, 234, 9-14. [CrossRef]

54. Hernandez-Lopez, M.J.; Prieto, J.A.; Randez-Gil, F. Osmotolerance and leavening ability in sweet and frozen sweet dough. Comparative analysis between Torulaspora delbrueckii and Saccharomyces cerevisiae baker's yeast strains. Antonie Van Leeuwenhoek 2003, 84, 125-134. [CrossRef]

55. Spencer, J.F.T.; Spencer, D.M. Taxonomy: The names of the yeasts. In Yeasts in Natural and Artificial Habitats; Springer: Berlin/ Heidelberg, Germany, 1997; pp. 11-32. [CrossRef]

56. Renault, P.; Miot-Sertier, C.; Marullo, P.; Hernández-Orte, P.; Lagarrigue, L.; Lonvaud-Funel, A.; Bely, M. Genetic characterization and phenotypic variability in Torulaspora delbrueckii species: Potential applications in the wine industry. Int. J. Food Microbiol. 2009, 134, 201-210. [CrossRef] [PubMed]

57. Lu, Y.; Chua, J.Y.; Voon, M.K.W.; Huang, D.; Lee, P.R.; Liu, S.Q. Effects of Different Inoculation Regimes of Torulaspora delbrueckii and Oenococcus oeni on Fermentation Kinetics and Chemical Constituents of Durian Wine. South Afr. J. Enol. Vitic. 2017, 38, 273-285. [CrossRef]

58. Romano, P.; Ciani, M.; Fleet, G.H. Yeasts in the Production of Wine; Springer: New York, NY, USA, 2019; pp. 81-115. [CrossRef]

59. Wei, J.; Zhang, Y.; Yuan, Y.; Dai, L.; Yue, T. Characteristic fruit wine production via reciprocal selection of juice and nonSaccharomyces species. Food Microbiol. 2019, 79, 66-74. [CrossRef]

60. Ebeler, S.E. Analytical Chemistry: Unlocking the Secrets of Wine Flavor. Food Rev. Int. 2001, 17, 45-64. [CrossRef]

61. Lambrechts, M.G.; Pretorius, I.S. Yeast and its Importance to Wine Aroma-A Review. South Afr. J. Enol. Vitic. 2000, 21, 97-129. [CrossRef] 
62. Belda, I.; Ruiz, J.; Esteban-Fernández, A.; Navascués, E.; Marquina, D.; Santos, A.; Moreno-Arribas, M. Microbial contribution to wine aroma and its intended use for wine quality improvement. Molecules 2017, 22, 189. [CrossRef]

63. Eliodório, K.P.; e Cunha, G.C.D.G.; Müller, C.; Lucaroni, A.C.; Giudici, R.; Walker, G.M.; Alves, S.L., Jr.; Basso, T.O. Advances in yeast alcoholic fermentations for the production of bioethanol, beer and wine. Adv. Appl. Microbiol. 2019, 109, 61-119. [CrossRef]

64. Jones, G.V.; White, M.A.; Cooper, O.R.; Storchmann, K. Climate change and global wine quality. Clim. Chang. 2005, 73, 319-343. [CrossRef]

65. Taillandier, P.; Lai, Q.P.; Julien-Ortiz, A.; Brandam, C. Interactions between Torulaspora delbrueckii and Saccharomyces cerevisiae in wine fermentation: Influence of inoculation and nitrogen content. World J. Microbiol. Biotechnol. 2014, 30, 1959-1967. [CrossRef]

66. Michel, M.; Kopecká, J.; Meier-Dörnberg, T.; Zarnkow, M.; Jacob, F.; Hutzler, M. Screening for new brewing yeasts in the nonSaccharomyces sector with Torulaspora delbrueckii as model. Yeast 2016, 33, 129-144. [CrossRef] [PubMed]

67. Gibson, B.; Dahabieh, M.; Krogerus, K.; Jouhten, P.; Magalhães, F.; Pereira, R.; Siewers, V.; Vidgren, V. Adaptive laboratory evolution of ale and lager yeasts for improved brewing efficiency and beer quality. Annu. Rev. Food Sci. Technol. 2020, 11, 23-44. [CrossRef] [PubMed]

68. King, A.J.; Dickinson, J.R. Biotransformation of hop aroma terpenoids by ale and lager yeasts. FEMS Yeast Res. $2003,3,53-62$. [CrossRef]

69. Canonico, L.; Agarbati, A.; Comitini, F.; Ciani, M. Torulaspora delbrueckii in the brewing process: A new approach to enhance bioflavour and to reduce ethanol content. Food Microbiol. 2016, 56, 45-51. [CrossRef]

70. Arrizon, J.; Morel, S.; Gschaedler, A.; Monsan, P. Fructanase and fructosyltransferase activity of non-Saccharomyces yeasts isolated from fermenting musts of Mezcal. Bioresour. Technol. 2012, 110, 560-565. [CrossRef]

71. la Torre-González, D.; Javier, F.; Narváez-Zapata, J.A.; Taillandier, P.; Larralde-Corona, C.P. Mezcal as a novel source of mixed yeasts inocula for wine fermentation. Processes 2020, 8, 1296. [CrossRef]

72. Wei, J.; Wang, S.; Zhang, Y.; Yuan, Y.; Yue, T. Characterization and screening of non-Saccharomyces yeasts used to produce fragrant cider. LWT 2019, 107, 191-198. [CrossRef]

73. Lorenzini, M.; Simonato, B.; Slaghenaufi, D.; Ugliano, M.; Zapparoli, G. Assessment of yeasts for apple juice fermentation and production of cider volatile compounds. LWT 2019, 99, 1-18. [CrossRef]

74. Lachance, M.A. Yeast communities in a natural tequila fermentation. Antonie Van Leeuwenhoek 1995, 68, 151-160. [CrossRef] [PubMed]

75. Chua, J.Y.; Lu, Y.; Liu, S.Q. Evaluation of five commercial non-Saccharomyces yeasts in fermentation of soy (tofu) whey into an alcoholic beverage. Food Microbiol. 2018, 76, 533-542. [CrossRef]

76. Ho, V.T.T.; Zhao, J.; Fleet, G. Yeasts are essential for cocoa bean fermentation. Int. J. Food Microbiol. 2014, 174, 72-87. [CrossRef] [PubMed]

77. Visintin, S.; Ramos, L.; Batista, N.; Dolci, P.; Schwan, F.; Cocolin, L. Impact of Saccharomyces cerevisiae and Torulaspora delbrueckii starter cultures on cocoa beans fermentation. Int. J. Food Microbiol. 2017, 257, 31-40. [CrossRef] [PubMed]

78. Blaisonneau, J.; Sor, F.; Cheret, G.; Yarrow, D.; Fukuhara, H. A Circular Plasmid from the Yeast Torulaspora delbrueckii. Plasmid 1997, 38, 202-209. [CrossRef]

79. Andrade, R.P.; Oliveira, D.R.; Lopes, A.C.A.; de Abreu, L.R.; Duarte, W.F. Survival of Kluyveromyces lactis and Torulaspora delbrueckii to simulated gastrointestinal conditions and their use as single and mixed inoculum for cheese production. Food Res. Int. 2019, 125, 1-12. [CrossRef]

80. Ferreira, A.D.; Viljoen, B.C. Yeasts as adjunct starters in matured Cheddar cheese. Int. J. Food Microbiol. 2003, 86, 131-140. [CrossRef]

81. Psani, M.; Kotzekidou, P. Technological characteristics of yeast strains and their potential as starter adjuncts in Greek-style black olive fermentation. World J. Microbiol. Biotechnol. 2006, 22, 1329-1336. [CrossRef]

82. da Mota, M.C.B.; Batista, N.N.; Rabelo, M.H.S.; Ribeiro, D.E.; Borém, F.M.; Schwan, R.F. Influence of fermentation conditions on the sensorial quality of coffee inoculated with yeast. Food Res. Int. 2020, 136, 109482. [CrossRef]

83. Bressani, A.P.P.; Martinez, S.J.; Sarmento, A.B.I.; Borém, F.M.; Schwan, R.F. Influence of yeast inoculation on the quality of fermented coffee (Coffea arabica var. Mundo Novo) processed by natural and pulped natural processes. Int. J. Food Microbiol. 2021, 343, 109107. [CrossRef] [PubMed]

84. Al-Qaysi, S.A.S.; Abdullah, N.M.; Jaffer, M.R.; Abbas, Z.A. Biological Control of Phytopathogenic Fungi by Kluyveromyces marxianus and Torulaspora delbrueckii Isolated from Iraqi Date Vinegar. J. Pure Appl. Microbiol. 2021, 15, 300-311. [CrossRef]

85. Ribeiro, L.S.; Ribeiro, D.E.; Evangelista, S.R.; Miguel, M.G.D.C.P.; Pinheiro, A.C.M.; Borém, F.M.; Schwan, R.F. Controlled fermentation of semi-dry coffee (Coffea arabica) using starter cultures: A sensory perspective. LWT-Food Sci. Technol. 2017, 82, 32-38. [CrossRef]

86. Compagno, C.; Ranzi, B.M.; Martegani, E. Yeast $2 \mu \mathrm{m}$ vectors replicate and undergo recombination in Torulaspora delbrueckii. Mol. Microbiol. 1989, 3, 1003-1010. [CrossRef] [PubMed]

87. Watanabe, Y.; Yashiki, Y.; Sultana, G.N.N.; Maruyama, M.; Kangawa, K.; Tamai, Y. Cloning and sequencing of phospholipase B gene from the yeast Torulaspora delbrueckii. FEMS Microbiol. Lett. 1994, 124, 29-34. [CrossRef]

88. Watanabe, Y.; Imai, K.; Oishi, H.; Tamai, Y. Disruption of phospholipase B gene, PLB1, increases the survival of baker's yeast Torulaspora delbrueckii. FEMS Microbiol. Lett. 1996, 145, 415-420. [CrossRef] 
89. Hernandez-Lopez, M.J.; Blasco, A.; Prieto, J.A.; Randez-Gil, F. Ura-Host strains for genetic manipulation and heterologous expression of Torulaspora delbrueckii. Int. J. Food Microbiol. 2003, 86, 79-86. [CrossRef]

90. Pacheco, A.; Almeida, M.J.; Sousa, M.J. Improved gene disruption method for Torulaspora delbrueckii. FEMS Yeast Res. 2009, 9 , 158-160. [CrossRef]

91. Pacheco, A.; Donzella, L.; Hernandez-Lopez, M.J.; Almeida, M.J.; Prieto, J.A.; Randez-Gil, F.; Morrissey, J.P.; Sousa, M.J. Hexose transport in Torulaspora delbrueckii: Identification of Igt1, a new dual-affinity transporter. FEMS Yeast Res. 2020, 20, foaa004. [CrossRef]

92. Raschmanová, H.; Weninger, A.; Glieder, A.; Kovar, K.; Vogl, T. Implementing CRISPR-Cas technologies in conventional and non-conventional yeasts: Current state and future prospects. Biotechnol. Adv. 2018, 36, 641-665. [CrossRef]

93. van Wyk, N.; Kroukamp, H.; Espinosa, M.I.; von Wallbrunn, C.; Wendland, J.; Pretorius, I.S. Blending wine yeast phenotypes with the aid of CRISPR DNA editing technologies. Int. J. Food Microbiol. 2020, 324, 108615. [CrossRef] [PubMed]

94. Donzella, L.; Varela, J.A.; Sousa, M.J.; Morrissey, J.P. Identification of novel pentose transporters in Kluyveromyces marxianus using a new screening platform. FEMS Yeast Res. 2021, 21, 1-11. [CrossRef] [PubMed]

95. Vilela, A. An Overview of CRISPR-Based Technologies in Wine Yeasts to Improve Wine Flavor and Safety. Fermentation 2021, 7, 5. [CrossRef]

96. Catrileo, D.; Acuña-Fontecilla, A.; Godoy, L. Adaptive Laboratory Evolution of Native Torulaspora debrueckii YCPUC10 with enhanced ethanol resistance and evaluation in co-inoculated fermentation. Front. Microbiol. 2020, 11, 1-13. [CrossRef] [PubMed]

97. DiCarlo, J.E.; Norville, J.E.; Mali, P.; Rios, X.; Aach, J.; Church, G.M. Genome engineering in Saccharomyces cerevisiae using CRISPR-Cas systems. Nucleic Acids Res. 2013, 41, 4336-4343. [CrossRef]

98. Turnbull, C.; Lillemo, M.; Hvoslef-Eide, T.A. Global Regulation of Genetically Modified Crops Amid the Gene Edited Crop Boom-A Review. Front. Plant Sci. 2021, 12, 258. [CrossRef]

99. Jorasch, P. Will the EU stay out of step with science and the rest of the world on plant breeding innovation? Plant Cell Rep. 2020, 39, 163-167. [CrossRef]

100. Menz, J.; Modrzejewski, D.; Hartung, F.; Wilhelm, R.; Sprink, T. Genome edited crops touch the market: A view on the global development and regulatory environment. Front. Plant Sci. 2020, 11, 1-17. [CrossRef]

101. Vives-Vallés, J.A.; Collonnier, C. The judgment of the CJEU of 25 July 2018 on mutagenesis: Interpretation and interim legislative proposal. Front. Plant Sci. 2020, 10, 1813. [CrossRef] [PubMed]

102. McHughen, A. A critical assessment of regulatory triggers for products of biotechnology: Product vs. process. GM Crop. Food 2016, 7, 125-158. [CrossRef]

103. Smyth, S.J. Canadian regulatory perspectives on genome engineered crops. GM Crop. Food 2017, 8, 35-43. [CrossRef] [PubMed]

104. Wolt, J.D.; Wolf, C. Policy and Governance Perspectives for Regulation of Genome Edited Crops in the United States. Plant Sci. 2018, 9, 1-12. [CrossRef] [PubMed]

105. Coulon, J.; Husnik, J.I.; Inglis, D.L.; van der Merwe, G.K.; Lonvaud, A.; Erasmus, D.J.; van Vuuren, H.J. Metabolic Engineering of Saccharomyces cerevisiae to Minimize the Production of Ethyl Carbamate in Wine. Am. J. Enol. Vitic. 2006, 57, 113-124.

106. Grossmann, M.; Kießling, F.; Singer, J.; Schoeman, H.; Schröder, M.B.; von Wallbrunn, C. Genetically modified wine yeasts and risk assessment studies covering different steps within the wine making process. Ann. Microbiol. 2011, 61, 103-111. [CrossRef]

107. Husnik, J.I.; Volschenk, H.; Bauer, J.; Colavizza, D.; Luo, Z.; Van Vuuren, H.J. Metabolic engineering of malolactic wine yeast. Metab. Eng. 2006, 8, 315-323. [CrossRef]

108. Dragosits, M.; Mattanovich, D. Adaptive laboratory evolution-principles and applications for biotechnology. Microb. Cell Factories 2013, 12, 1-17. [CrossRef] [PubMed]

109. Ferea, T.L.; Botstein, D.; Brown, P.O.; Rosenzweig, R.F. Systematic changes in gene expression patterns following adaptive evolution in yeast. Proc. Natl. Acad. Sci. USA 1999, 96, 9721-9726. [CrossRef]

110. Jansen, M.L.; Diderich, J.A.; Mashego, M.; Hassane, A.; de Winde, J.H.; Daran-Lapujade, P.; Pronk, J.T. Prolonged selection in aerobic, glucose-limited chemostat cultures of Saccharomyces cerevisiae causes a partial loss of glycolytic capacity. Microbiology 2005, 151, 1657-1669. [CrossRef]

111. Dhar, R.; Sägesser, R.; Weikert, C.; Yuan, J.; Wagner, A. Adaptation of Saccharomyces cerevisiae to saline stress through laboratory evolution. J. Evol. Biol. 2011, 24, 1135-1153. [CrossRef] [PubMed]

112. Novo, M.; Gonzalez, R.; Bertran, E.; Martínez, M.; Yuste, M.; Morales, P. Improved fermentation kinetics by wine yeast strains evolved under ethanol stress. LWT-Food Sci. Technol. 2014, 58, 166-172. [CrossRef]

113. Chen, S.; Xu, Y. Adaptive evolution of Saccharomyces cerevisiae with enhanced ethanol tolerance for Chinese rice wine fermentation. Appl. Biochem. Biotechnol. 2014, 173, 1940-1954. [CrossRef]

114. Avrahami-Moyal, L.; Engelberg, D.; Wenger, J.W.; Sherlock, G.; Braun, S. Turbidostat culture of Saccharomyces cerevisiae W303-1A under selective pressure elicited by ethanol selects for mutations in SSD1 and UTH1. FEMS Yeast Res. 2012, 12, 521-533. [CrossRef]

115. Franco-Duarte, R.; Bigey, F.; Carreto, L.; Mendes, I.; Dequin, S.; Santos, M.A.; Pais, C.; Schuller, D. Intrastrain genomic and phenotypic variability of the commercial Saccharomyces cerevisiae strain Zymaflore VL1 reveals microevolutionary adaptation to vineyard environments. FEMS Yeast Res. 2015, 15, 1-13. [CrossRef] [PubMed]

116. da Silveira, F.A.; de Oliveira Soares, D.L.; Bang, K.W.; Balbino, T.R.; de Moura Ferreira, M.A.; Diniz, R.H.S.; de Lima, L.A.; Brandão, M.M.; Villas-Bôas, S.G.; da Silveira, W.B. Assessment of ethanol tolerance of Kluyveromyces marxianus CCT 7735 selected by adaptive laboratory evolution. Appl. Microbiol. Biotechnol. 2020, 104, 7483-7494. [CrossRef] [PubMed] 
117. Mo, W.; Wang, M.; Zhan, R.; Yu, Y.; He, Y.; Lu, H. Kluyveromyces marxianus developing ethanol tolerance during adaptive evolution with significant improvements of multiple pathways. Biotechnol. Biofuels 2019, 12, 1-15. [CrossRef] [PubMed]

118. Adamo, G.M.; Lotti, M.; Tamas, M.J.; Brocca, S. Amplification of the CUP1 gene is associated with evolution of copper tolerance in Saccharomyces cerevisiae. Microbiology 2012, 158, 2325-2335. [CrossRef] 